\title{
THE IMPACT OF STRUCTURAL AND COHESION FUNDS ON THE ECONOMY OF BIHOR COUNTY DURING 2007-2013 PROGRAMMING PERIOD
}

\author{
Felix-Angel Popescu \\ Doctoral School of Economics, Faculty of Economic Sciences, University of Oradea, \\ Oradea, Romania \\ felixangelpopescu@gmail.com
}

\begin{abstract}
The author uses TIATOOL model simulations, in order to reveal the potential impact generated by the Romanian Operational Programs 2007-2013 funded projects in Bihor county, on a set of 34 socio-economic indicators, for which individual intensities and weights were estimated by the author, based on the actual numbers of projects, their scope and the amounts of money absorbed by project beneficiaries. The readers should not expect a high impact of Structural and Cohesion funds on the economy of Bihor county, on short term, because these funds, like the rest of community funds, have a very pronounced redistributive role, which means that the dimension of the necessary expenditures for the implementation of projects counterbalances its revenues dimension, the amortization of such investments being made on long term. The novelty of such research is the fact that the Community authorities (in this case the European Commission) investigate the impact of Community funds only at policy level (cohesion, regional development and employment, territorial cooperation) and only in a comparative spectrum between national and regional figures, and the Romanian authorities (the Ministry of European Funds, the Operational Programs Managing Authorities) carry out impact assessments only at national and regional level.
\end{abstract}

Keywords: Structural, Cohesion, funds, impact, Bihor, economy.

JEL classification: $011,041$.

\section{Introduction}

Although the author did not identify local impact assessments during the 2000-2006 programming period, it can be said that for Bihor County, the starting economic base represented the period 1994-1999, the level of the county GDP per capita as compared to the other counties of Romania, being placed in an ascending slope, starting with 2000 (the beginning of the period for the pre-accession funds), 2005 (during the implementation of the pre-accession funds), respectively 2010 (at 4 years after the pre-accession period, and during the implementation of the Structural and Cohesion Funds). Between these years, the internal divergence at county level deepened in Romania, but there was also an external convergence towards the European Union (Ionescu-Heroiu et al., 2013: 32).

It is worth mentioning that Bihor County also evolved, especially in the period 2005-2010, with a GDP / capita significantly better than in 2000. Certainly, the economic base of Bihor County in 1995 provided a continuity of development. However, the lower contribution of European funds in the period 2008-2010 determined Bihor County to qualify only for the medium developed counties ranking in 2011, according to the Index of Local Human Development (IDUL) (Ionescu-Heroiu et al., 2013: 254). In fact, in relation to the realities of the years 2015-2016, the author considers that Bihor County has made the transition to the category of developed counties.

Besides, in 2009, the year when the absorption of Structural and Cohesion funds in Bihor county, as in most of the counties in Romania, showed a late debut that was caused by 
difficult administrative procedures, it is noticed that Bihor county managed to maintain itself between the first 10 counties as a share of the county GDP in the national GDP (in relation to the economic evolution from 1995 to 2009). At the level of 2010, the effects of the pre-accession funds absorbed in the Bihor county were felt in the degree of urbanization. However, there were barriers encountered at county level in the absorption of Structural and Cohesion funds, mentioned by Berinde et al (2012: 14), in this case: "the lack of training programs, politicizing the way of selecting beneficiaries, low transparency of the establishment criteria of beneficiaries, excessive bureaucracy in the elaboration and approval of projects, difficulties of co-financing on the part of the beneficiary [...] ", which at the level of 2010, could have leaded towards a distancing between urbanization and development. The problem of the economic connections of Bihor County with the other counties in the North-West development region seems to be an atypical situation, as Cluj-Napoca, the growth pole of the region benefits from more favourable connections with development poles in the Centre region (Alba-lulia, Târgu-Mureş, Sibiu) (Ionescu-Heroiu et al., 2013: 151), generating a distance from the neighbouring development poles: Oradea, Satu Mare, Zalău (Cristea et al., 2017: 63).

Despite these issues, it is noticed that the economic and social status of Bihor county has improved over the years: the Gross Domestic Product per capita in Bihor county since its accession to the European Union has increased from 6000 Euro in 2007 to 7950 Euro in 2015, that is from $23 \%$ of the European average in 2007 to $28 \%$ in 2015 (INSSE, 2016).

Could this be an indirect effect of the Structural and Cohesion funds attracted in Bihor county during the 2007-2013 programming period? The state of knowledge is narrowing when the effects of the implementation of projects financed from community sources at regional, county and urban / rural level are discussed. As previous papers of the author presented the literature review and theoretical aspects of impact evaluation methodology at a wider level (Popescu et al., 2016a; Popescu et al., 2017a), this article focuses on smaller issues at Bihor county level, through a research of the author regarding the possibilities to assess the impact of the European funded projects in the local economy.

Regarding the available assessment methods at local level, Popa et al. (2013), Panagiotis (2014) and Dabrowski (2015) show that in most cases, there are potential positive effects of Structural and Cohesion funds. It can be added that these effects are compromised by the low capacity of European funds management at both public institutions or private organizations in villages, towns and municipalities, or their often use for non-performing investments (lorga et al., 2011). It is also notable the observation of Lincaru et al. (2015), that in most situations, the expenditures resulted from European funded projects at local level are addressed independently of other public policies and sometimes even apart from the local development strategies (Popescu, 2016c). However, Moldovan et al. (2016) identified potential effects of European funds in rural areas of North-West region.

\section{Methodology}

For the impact evaluation methods for Structural and Cohesion Funds, the author has identified the TIATOOL instrument, which has a high degree of territorial disaggregation. The model has an online platform, namely TIATOOL (ESPON, 2017), which requires a username and a password. Figure 1 presents the intensities of the impact vectors which the author had to estimate in the input phase.

In the input section, in order to determine if the public policy had stronger or weaker effects on the territory, respectively if these effects are advantageous or disadvantageous, the author is required to indicate intensity values for each indicator, ranging from Strong Disadvantage (Symbol "--"), Weak Disadvantage (Symbol "-“), Weak Advantage (Symbol “+”), Strong Advantage (Symbol “++"), to Unknown Effect (Symbol "?") or No effect (Symbol 
"0"); after this phase, the author had to estimate the weight of the impact for each indicator, ranging from minor, moderate to high or very high impact.

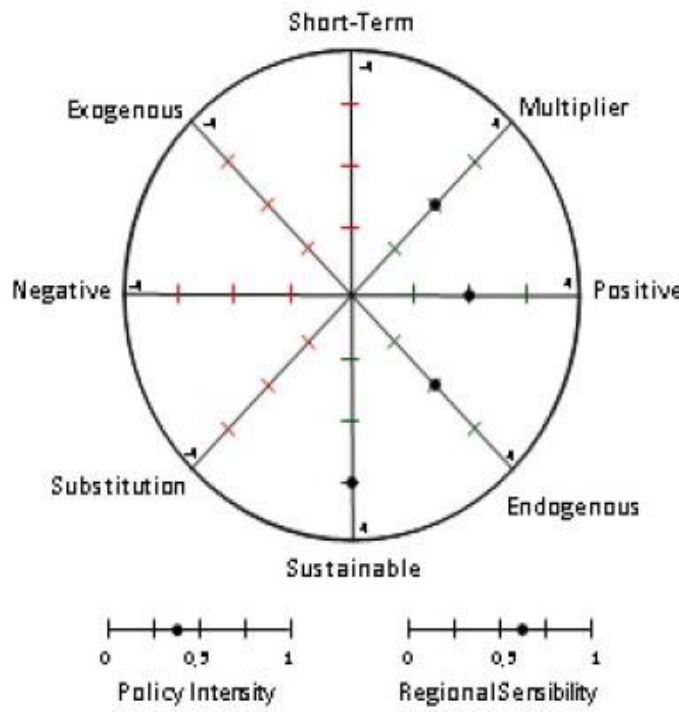

$4=$ Very significant positive impacts

3 = Significant positive impacts

2 = Moderate positive impacts

$1=$ Low positive impacts

$0=$ Null impacts

-1 = Low negative impacts

- 2 = Moderate negative impacts

- 3 = Significant negative impacts

- 4 = Very significant negative impacts

Figure 1: Estimated impact vectors in TIATOOL

Source: Medeiros (2014: 29-30)

Based on the results of projects implementation on the Romanian Operational Programs, the author estimated the 34 indicators of the model, which must be viewed as deviations (in percentage and intensity, from the zero European funding scenario to the actual 2007-2013 European funding scenario in Bihor county (ex-post impact evaluation 2013-2023):

a. Innovation category, with the indicators:

- Employment in technology sectors: Weak advantage +, Moderate impact $57.84 \%$

- R\&D Expenditure: Weak Advantage +, Moderate impact 2.27\%

b. Economic development category, with the indicators:

- Entrepreneurship: Strong advantage ++, Very high impact $88.35 \%$

- Economic growth (GDP/capita): Strong Advantage ++; Very high impact $96.89 \%$

- Tourist intensity: Weak advantage +, Moderate impact $12.55 \%$

c. Employment category, with the indicators:

- Employment in tertiary sector: Weak advantage +, Moderate impact $75.99 \%$

- Employment in secondary sector: Weak advantage +, Moderate impact 39.58\%

- Employment in primary sector: Weak advantage +, Moderate impact $16.85 \%$

d. Accessibility category, with the indicators:

- Potential accessibility by rail: Weak advantage +, Minor impact $37.75 \%$

- Potential accessibility by road: Weak advantage +, Moderate impact 34.26\%

- Access to high-level passenger transport: No effect 0, No exposure $100 \%$

- Potential accessibility by air: Strong advantage ++, Very high impact $0.69 \%$

e. Health category, with the indicators:

- Health life expectancy at birth: Unknown effect?, No exposure 100\%

- Number of people exposed to noise: Unknown effect?, No exposure $100 \%$

f. Governance category, with the indicators:

- Interregional cooperation: Weak advantage +, Moderate impact 6.61\%

- Government effectiveness: Weak disadvantage -, Minor impact 72.65\% 
g. Social disparities category, with the indicators:

- Early leavers from education and training: Weak advantage + Moderate impact $37.27 \%$

- Out migration / brain drain: Weak disadvantage -, Minor impact $28.47 \%$

- Unemployment rate: Strong advantage ++, High impact $84.76 \%$

- Disposable income: Unknown effect?, No exposure 100\%

- Female employment: Weak advantage +, Moderate impact 3.13\%

- People at risk of poverty, social exclusion: Weak advantage +Moderate impact $42.91 \%$

h. Natural hazards category, with the indicators:

- Exposure to landslides: Unknown effect?, No exposure 100\%

- Exposure to winter avalanches: Unknown effec ?, No exposure 100\%

- Exposure to floods: Strong advantage +, High impact $74.88 \%$

i. Environment category, with the indicators:

- Pollutants in soil and ground/surface waters: Unknown effect ?, No exposure 100\%

- Pollutants in air (PM10): Unknown effect?, No exposure 100\%

- Emissions of CO2: Weak advantage +, Moderate impact $0.40 \%$

- Water resources: Weak advantage +, Minor impact $0.15 \%$

j. Protection and conservation of land category, with the indicators:

- Conservation of forests and semi natural areas: Weak advantage + Minor impact $4.58 \%$

- Conservation of cultural heritage: Strong advantage ++, High impact 55.64\%

- Protected areas (Natura 2000): Weak advantage +, Minor impact 0.29\%

- Share of agricultural areas: Strong advantage ++, High impact $28.14 \%$

- Share of artificial areas / soil sealing: Unknown effect?, No exposure 100\%

\section{Results and discussions}

After running the simulations, the TIATOOL model generated a long-term impact (2013-2023) map for each indicator according to the intensity and weight estimated by the author.

According to the simulations, the Bihor county economy has, in the long run, a high impact on the employment rate in the technology and research sectors. The economic reality of the county confirms these estimates, as the investments from Structural and Cohesion funds in the Eurobusiness I, II and III industrial platforms in Oradea, as well as in the industrial platform in Borș commune have led to the establishment of local employers in the technological sector; in fact, these sectors are turning to emerging economies such as Romania, Bulgaria, Hungary, Poland, Lithuania, Estonia, Latvia, these countries being most prone to specific investments. However, the opening of the Bihor county economy to these sectors is still somewhat fragile, but the author estimates that in the long run, this simulated impact will also generate side effects, such as increased demand for technical schooling and related training.

However, there is a long-term stagnation in R\&D expenditure both in Bihor County and in almost all Member States. The cause can be motivated by the fact that investments from European funds can indeed create technology clusters or focus on creating business incubators in areas with development potential, but continuity in ensuring research and development budgets must be provided either from the public budget, either from private funding, a problem that will present enough shortcomings in the European Union. In fact, the share of high added value services is insignificant in Bihor County, and the contribution to national turnover in R\&D activities is equally insignificant, fact from which it can be deduced that the simulated impact presents plausible prospects, in the long term.

Investments from European funds will have an impact on the share of private enterprises in the long run. If the projects implemented in the Operational Programs in Bihor County are analysed more closely, it will be noticed that almost a third of them represent investments in the private sector, which can lead only to the opinion that a multiplier effect of the money 
infusions in the private capital generate sustainable growth in this sector. In fact, this trend is generalized in all Member States, which can strengthen the author's idea that Bihor County will succeed in continuing economic development and counterbalance growth in services with the emergence of new industrial branches.

In the author's opinion, economic growth, expressed in GDP per capita, does not necessarily have to be interpreted as a direct effect of Community funding; great attention must be paid to the demographic masses of Bihor county, as there have been massive emigrations to other countries over the last 5 years, which inevitably generated a higher GDP / inhabitant; indirectly, the projects implemented during the 2007-2013 programming period have produced a visible financial effect at the level of all Member States, the figures being confirmed by the fact that Romania holds the first position in economic growth at the level of 2017, which offers added credibility to support the estimates below.

It is noticeable that the intensity of the tourists will not be significantly influenced by the projects funded by Structural and Cohesion funds, although the author believes that there are numerous tourist attractions in Bihor county renovated and returned to the tourist circuit by projects designed to increase the number of tourists; as demonstrated in a previous article by the author (Popescu et al., 2016), it is more difficult to assess the impact of tourism-related projects, especially by counterfactual methods. It is noticed that there is a general trend across all EU Member States, so it can be said that there are weak direct effects between a touristic project rehabilitated by European funds and the intensity of the tourists; however, they can prevail over indirect effects.

According to the simulations, the employment rate in the tertiary sector (the services) will have a minor impact from the European funded projects in Bihor county, which can be explained by the fact that the projects were generally focused on the procurement of equipment or materials and less on jobs creation. Another explanation may be the fact that there is an increased labour migration tendency from countries such as Romania, Bulgaria, Hungary, the Czech Republic, Slovakia, Poland to other EU Member States where the tertiary sector manages to integrate a large part of the immigrants and where the share of economic activities in gross value added is directed to the tertiary sector. The secondary sector (the industry) places Bihor County on a moderate growth trend over the period 2013-2023, which is an obvious effect of the investments from European funds due to the development projects of the industrial parks. However, it is noticed that emerging economies, such as Romania, Hungary, Poland, Portugal, the Czech Republic, Slovakia, Estonia, are delineated to areas with a long history of industrialization, such as Germany, Northern and Central Italy, Eastern Spain and Southern Sweden. Indeed, in the long run, a concentration of industry in Central and Southeast Europe is emerging, which may be associated with a positive effect of the Cohesion policy. However, it will be interesting to analyse, at the end of the 2014-2020 period, how each county will succeed in capitalizing the growth potential in the secondary sector, and Bihor County will certainly be favoured by the border settlement.

There should also not be neglected the agriculture of Bihor county, because the investments from European funds have generated a high production potential during the period 2007-2013, continued by the same trend in 2014-2020; there is a noticeable impact of a slight increase in the employment rate in this sector at Bihor county level, because Romanian agriculture is currently in a transition period in terms of its ability to have high added value products. This results in a certain funding gap for both organic farmers and livestock farmers, translated into a cost saving with staff and implicitly through an increasing rate of automation of specific technological processes. It should be noted, however, that this situation is generalizing at EU level.

The author appreciates that investments in railway infrastructure in Bihor county are reduced, but, in the long run, investments from Community funding for this objective will generate a moderate impact. Moreover, the most urgent need in this area is the 
electrification of the railway link between Oradea and Cluj-Napoca, an objective which, although not within the powers of the local administration, could have received greater support from the central administration if it had been included in the county and regional development strategies 2007-2013. This can also be motivated by the fact that the importance of both freight and passenger rail transport has lost ground, the first segment being detrimental to car transporters, and the second segment to the detriment of air carriers. Street infrastructure in Bihor County is expected to have a moderate impact from European funds investment, which is obvious when studying the projects implemented during the 2007-2013 period. In this respect, the highest impact will continue to prevail in countries that have had a consolidated street infrastructure long before Community funds, such as counties from Germany, Great Britain, Belgium, the Netherlands, Luxembourg, Denmark, and northern Italy or counties dispersed from Spain (Popescu et al., 2015). In fact, the development strategy of Bihor County 2007-2013 has not produced sustainable objectives to cover a consistent degree of street infrastructure with community investment, with much of the work being settled from national funds.

The author chose not to estimate an effect for Bihor County regarding the high-quality passenger transport infrastructure, which would translate into motorways, as such investments did not occur at county level and will not occur even during the period programming period 2014-2020. In addition, inter-nodal transport, the link to the trans-European Transport Network, as well as the modernization of the public transport networks (tram, bus, subway), were not funded by European funds at Bihor County level and were not included in the Development Strategies 2007-2013, 2014-2020.

The project of airport infrastructure rehabilitation in Bihor County (Oradea International Airport) has already produced positive effects in the period 2016-2017, but in the long run it will also depend on the efficiency of the air routes, which is why the expected growth impact until 2023 is a minor one. This is also due to the fact that Oradea International Airport is at an early stage of development and the investment made by European funds cannot, on its own, increase the number of passengers, the number of flights, etc. This depends very much also on the strategies of the neighbouring airports and the capacity of Bihor County to attract a wide spectrum of opportunities for the development of the air routes, because the county has lost ground to the competitors due to the non-production of investments at the right time in the pre-accession period 2000-2006.

Life expectancy at birth is a very rare indicator in county or regional development strategies, and for Bihor County, this indicator is being estimated somewhere around the age of 72 (INSSE, 2017). The author chose to have an unknown effect on this indicator, as there are very few investments from European funds that have a concrete effect on this indicator; most probably reported at the level of Bihor County, some projects for the modernization of hospital ambulatories, could somewhat justify a minor effect of improving the longevity of life. It is, however, obvious that in counties and generally in countries where health services are of high quality, there is a positive differentiation of life expectancy at birth.

The same explanation is also given by the author for the number of people exposed to noise, as the effects of European fund investments on this issue are unknown. In fact, in Bihor County and probably across the country, there are no measurement methods to ensure the accuracy of the results. The theme of noise pollution in Bihor county could be debated on the relationship between certain industrial activities and the neighbourhood of residential areas, namely the noise produced by the railway and the street infrastructure in relation to the residential areas, and recommendations on this issue can be included in the urban development plans in the territorial administrative units of the county.

For the interregional cooperation indicator, the impact of community funding in Bihor County will be moderate in the long run, as numerous projects have been implemented through the Hungary - Romania Cross Border Cooperation Program 2007-2013 (Popescu, 2017b). It is noticed that the North-West region is the only one in the country that is delineated by the rest 
of the regions, and the Romanian counties together with the Hungarian counties participating in the cooperation program have succeeded in implementing projects which, by 2023, will ensure positive effects from interregional cooperation. This situation reinforces the author's statement that the dualism of funding sources of Bihor County (cross-border cooperation program and operational programs) provides a competitive development advantage.

The efficiency of governance is negatively affected by investments from European funds, because on one hand, the projects implemented during the period 2007-2013 have generated a long line of deviations from Community rules, corruption cases, suspension of payments, cases of fraud, and so on As the author recalled, there are countries such as Bulgaria, Romania, the Czech Republic, Slovakia, Hungary, Poland, Lithuania, Latvia, and Italy, who have encountered many problems in the efficient management of European funds. On the other hand, the effectiveness of governance in relation to community funding is also determined by a series of barriers to beneficiaries' access to project implementation.

Concerning the early education dropout rate (18-24 years old group who did not graduate the upper secondary level), Bihor county and North West region target is to reduce this rate to less than 11\% (INSSE, 2017:7). Corrected with the simulated impact, the author feels that the expectations are realistic, and the simulations of the model have very high effects. In relation to the European fund investments in Bihor County, this objective can best be found in the rehabilitation of some schools, projects best suited to the European Agricultural Fund for Rural Development and Hungary - Romania Cross-border Cooperation Program 2007-2013.

Regarding the migration of intellectuals and highly qualified workforce, the author estimated a negative value and the model simulated a moderately negative impact on Bihor County and generally on most of the NUTS3 regions in the EU, as Community funding cannot stop such a phenomenon; however, the least affected regions are the polarized areas around the capitals. At present, Bihor County faces a lack of qualified workforce in technical fields; therefore, the establishment of vocational schools by industrial employers can put an end to the problem of labour replacement.

Certainly, in the long run, European funds will positively influence the unemployment rate in most NUTS3 regions. For this assertion, the scenario without European funds at the county level should be imagined, given that the predominant branch of industry in Bihor County focuses around shoe production (Popescu, 2016b) and the development strategies of municipalities, towns and communes, making abstraction of Community funding, do not contain realistic objectives of economic development and, implicitly, of employment (Popescu, 2016c). Moreover, criticized at national level, the tendency of the population and of the authorities to wait and hope for private investors, especially at the level of the municipalities and towns other than the county residence, respectively at the level of the communes, is perpetuated: unfortunately, there are fewer jobs generated by business with Romanian capital. The author did not reflect on the households' disposable income, as European funded projects are cost-generating and, until revenue is generated, depreciation occurs. In the long term, this explanation gets more plausible as the effects of private investment (upgrades, purchases of materials and services) do not generate immediate profit because the beneficiary either has to repay a bank loan or has appealed to own sources of co-financing, which in both cases means an impact on the capital in question. The consequences of this situation will inevitably be found in wage costs, purchases, and any other needs in the long run. On the other hand, investments in infrastructure, education, health and so on, can generate a cost reduction per citizen.

In the case of reducing the number of people at risk of poverty and social exclusion, the impact of projects is estimated at a moderate level, as there were measures financed at Community level in Bihor County to protect these categories of people (in addition to state aids). However, the county faces another type of social exclusion: the wages are too low to 
support the subsistence level, cumulated with the discrepancy between the minimum wage in the economy and the real salary, so well-trained professions or crafts are paid at a marginal level. From this perspective, poverty in Bihor County should not be understood only unilaterally, on the financial side, but also in terms of deficits in employment, education, health, living conditions and social segregation.

\section{In conclusion}

Regarding the results of TIATOOL simulation, the author appreciates that the Bihor county economy will, in the long run, return to the magnitude of the goals assumed by the development strategies and will succeed in breaking down the image of a county with a concentration of the footwear industry. Moreover, due to the economic decline and the non-production of private investments by the year 2000, due to slow and sometimes inconsistent efforts to engage projects with local impact in the pre-accession period 2000-2006, the Bihor county economy encountered a delay in development.

For the post-accession period 2007-2013, the author considers that there have not been implemented projects with economic viability meant to bring a strong development until 2023, besides the rehabilitation of Oradea International Airport and the creation of Eurobusiness I, II and III Industrial Parks, respectively Borș Industrial Park. From this perspective, it will be noticed that much of the 34 estimated indicators do not have a growth base: preservation of cultural heritage, forest patrimony, Natura 2000 regions, avalanches and landslides prevention, life expectancy at birth, noise exposure, railway infrastructure, street and public transport - are indicators that have benefited at a marginal level from the implementation of the projects implemented at county level.

It is noted, however, that significant effects will be found in the indicators that are always used with a positive update rate: the increase of the GDP / capita may be justified by the increase of the monetary transactions at the county level, but can be counterbalanced by the massive emigration of highly skilled labour force. Similarly, an insignificant increase in R\&D spending will result in staff cuts in the public sector, and a drop of production capacity in the private sector. At the same time, GDP growth per capita may be positively influenced by the increase in entrepreneurship, but it can also be negatively influenced by the inefficiency of governance and irrelevant interregional cooperation, especially if it is revealed the situation of projects implemented in other cities and communes than Oradea. Another correlation should be made between school drop-out rate, which gives positive long-term signals, with increasing employment rates in the primary, secondary and tertiary sectors, as the author believes that it is necessary to invest in industry, services or agriculture, but it also requires competent people. Finally, tourism can be an alternative to the development of the county, even if the author has found an insignificant impact of long-term community funding. Last but not least, agriculture will be an extremely favourable development niche for Bihor County. It is very difficult, in fact, to assess the economic impact of Cohesion policy, firstly because the data obtained cannot provide clear information on the net effects, at most they can illustrate the outcome (output) of the financed interventions and, secondly, analytical tools (macroeconomic models, counterfactual assessments, econometric methods) are required which use very technical language and are not accessible to the general public. A common mistake is that impact assessments mainly address GDP as the main variable, its growth effects being seen as a response to removing regional disparities; there are also variables that always give positive results to financial intervention, such as employment and social inequalities (European Commission, 2016). The indicators used in the author's estimates are not so common and presented at county statistics, so, as the effect of the separation of Structural and Cohesion funds flows cannot be highlighted in the main indicators at county level, the author states that the simulation of this model offers a potential and realistic analysis on the effects of the community projects and of their multipliers. 


\section{References}

Berinde, M. (Coord.), Budău, A., Popovici, M. and Coda M., 2012. Studiu privind modul de percepție a procesului de aderare a României la Uniunea Europeană de către cetățenii județului Bihor, Oradea: Editura Universității din Oradea.

Cristea, M., Mare, C., Moldovan, C., China, A., Farole, T., Vințan, A., Park, J., Garett, K., and Ionescu-Heroiu, M., 2017. Orașe magnet: Migrațiune și navetism în România, Washington: Banca Mondială, Banca Internațională pentru Reconstrucție și Dezvoltare.

Dabrowski, M., 2015. Doing more with less or doing less with less?Assessing EU cohesion policy financial instruments for urban development, Regional Studies,26 p.

European Commission, 2016. Measuring the impact of Structural and Cohesion Funds using the regression discontinuity design, Luxembourg: Publications Office of the European Union.

European Spatial Planning Observation Network ESPON, 2017. Quick Check on Territorial Impact Assesment TIATOOL [online], available at: http:/tiatool.espon.eu/tia/, [accessed 25.07.2017].

Institutul Național de Statistică INSSE, Principalii indicatori macroeconomici ai județului Bihor [online], available at: http://www.bihor.insse.ro/main.php?lang=fr\&pageid=538, [accessed 10.09.2016].

Institutul Național de Statistică INSSE, 2017. Regiunea Nord-Vest România. Statistici europene comparative, Bistrița-Năsăud.

Ionescu-Heroiu, M., Burduja, S., Sandu, D., Cojocaru, S.., Blankespoor, B., lorga, E., Moretti, M., Moldovan, C., Man, T., Rus, R. and van der Weide, R., 2013. Orașe competitive. Remodelarea geografiei economice a României, București: Banca Mondială, Ministerul Dezvoltării Regionale și Administrației Publice, Ministerul Fondurilor Europene.

Iorga, E., Alexandru, V. and Ercuș, L., 2011. Fondurile structurale: de la oportunitate de dezvoltare la buget de pradă. Șansele redresării României prin fonduri structurale, București: Institutul pentru Politici Publice.

Lincaru, C., Pirciog, S., Ciucă, V., Atanasiu, D. and Chiriac, B., 2015. A territorial profile of public expenditures at LAU2 level for 2007-2013 period in Romania, The USV Annals of economics and public administration, Vol. 15, Issue 1(21), pp. 204-213.

Medeiros, E., 2014. Cross-border cooperation and territorial impact assessment in the EU, Evaluační teorie a praxe 2(2), pp. 23-38.

Moldovan, B.A. and Pavel, A., 2016. Efectele accesului la finanțare nerambursabilă și la infrastructura de transport asupra dezvoltării economice locale în mediul rural din regiunea de dezvoltare Nord-Vest, Revista Transilvană de Științe Administrative, No. 2, pp. 140-152. Panagiotis, A., 2014. Local versus regime convergence regression models: a comparison of two approaches, GeoJournal, No. 80, pp.263-277.

Popa, A. and Dospinescu, A., 2013. Multipliers of Romanian economic structure: analysis in terms of input-output model. Actual Problems of Economics, No. 5(143), pp. 432-441.

Popescu, F.A. and Benea, C.B., 2015. Short overview of European roads and their financing, Annals of the University of Oradea - Economic Sciences, XXIV, pp. 106-112.

Popescu, F.A. and Berinde, M., 2016a. Theoretical aspects regarding Structural and Cohesion Funds impact evaluation methodology, Annals of the University of Oradea Economic Sciences, XXV, No. 2, pp. 106-116.

Popescu, F.A., 2016b. Researches regarding the dimension and relevance of European funding in Bihor county, Emerging markets economics and business. Contributions of young researchers, No. 4, University of Oradea Press. pp. 141-145. 
Popescu, F.A., 2016c. Bihor county: economy evolution, development strategies and European Funds perspective, Emerging markets economics and business. Contributions of young researchers, No. 4, University of Oradea Press. pp. 146-150.

Popescu, F.A. and Berinde, M., 2017a. Analysis regarding the instruments for impact evaluation of European funds across practitioners, Annals of the University of Oradea Economic Sciences, XXVI, No. 1, pp. 691-696.

Popescu, F.A., 2017b. Perspectives of HU-RO CBC 2007-2013 impact evaluation: economic benefits for Bihor county, Achievements, Contemporary Approaches and Perspectives in the Evaluation of Cross-border Cooperation, University of Oradea Press.

\section{Bio-note}

Felix - Angel Popescu holds a Ph.D. in economic sciences awarded by the Doctoral School of Economic Sciences, University of Oradea. His research interests focus on the impact of Structural and Cohesion funds on the national, regional and local economies, with emphasis on Bihor county of Romania, with topics like: the absorption degree of European funds, the possibilities of impact evaluation of implemented projects, the correlation degree between projects, operational programs and policies level. His background studies focus on interdisciplinary experiences: international relations, European studies, regional development, business administration, economics. 